\title{
Marine hydrodynamics between San Sebastián and Hondarribia (Guipúzcoa, northern Spain): field measurements and numerical modelling
}

\author{
ALMUDENA FONTÁN ${ }^{1}$, JULIEN MADER ${ }^{1}$, MANUEL GONZÁLEZ ${ }^{1}$, \\ ADOLFO URIARTE ${ }^{1}$, PAOLO GYSSELS ${ }^{1}$ AND MICHAEL B. COLLINS ${ }^{2}$ \\ ${ }^{1}$ Marine Research Division, Azti - Tecnalia. Herrera kaia, portualdea z/g, 20.110 Pasaia, Gipuzkoa, Spain. \\ E-mail: afontan@pas.azti.es \\ ${ }^{2}$ School of Ocean and Earth Science, University of Southampton, National Oceanography Centre, European Way, \\ Southampton SO14 3ZH, UK.
}

\begin{abstract}
SUMMARY: During 2000 and 2001 and at the beginning of 2002, current meters were deployed at 25, 50 and $110 \mathrm{~m}$ water depths along two transects: one offshore of San Sebastian and the other offshore of Hondarribia. At the same time, hydrographical cruises and the collection of sediment samples were undertaken over the coastal section. The aim of the study was to improve the knowledge of seasonal changes in the coastal water circulation. The main results obtained are three-dimensional measurements of water flow, a description of the seabed sedimentology between 50 and $90 \mathrm{~m}$ depth, and an improved description of the effect of the circulation patterns on the dispersion of pollutants. Two different patterns of surface water circulation were identified, related to oceanographic and meteorological conditions in autumn-winter and spring-summer. Analyses undertaken on three-dimensional current meter data also improved the understanding of seasonal variations in marine currents. All the field data were incorporated into a numerical model for the simulation of currents. This numerical model contributed, together with the field measurements, to the improvement of the description of general seasonal variability patterns in the currents. The effect of this circulation on the dispersion of pollutants was also analysed.
\end{abstract}

Keywords: marine hydrodynamics, field measurements, numerical modelling, pollution, dispersion.

RESUMEN: Hidrodinámica marina en el tramo costero entre SAn SEbastián y Hondarribia (Guipúzcoa, España): MEDIDAS DE CAMPO Y MODELIZACIÓN NUMÉRICA. - Durante los años 2000 y 2001 y principios de 2002 se ha mantenido en funcionamiento un operativo de correntímetros a 25, 50 y 110 metros de profundidad, a lo largo de dos transectos situados frente a San Sebastián y Hondarribia. Simultáneamente se realizaron campañas hidrográficas y recogida de muestras de sedimento dentro de la sección costera. El objetivo de este estudio fue mejorar la comprensión de los cambios estacionales de la circulación costera. Los principales resultados obtenidos fueron la medida tridimensional de la corriente marina, completar entre 50 y 90 metros de profundidad la caracterización sedimentológica y una mejor descripción del efecto de los patrones de circulación en la dispersión de contaminantes. Se han detectado dos esquemas de circulación marina superficial, asociados a las condiciones océano-meteorológicas de otoño-invierno y de primavera-verano. Asimismo, los datos tridimensionales de corrientes han permitido mejorar el conocimiento sobre las variaciones estacionales de las corrientes. Todos los datos obtenidos fueron implementados en un modelo numérico de simulación de las corrientes, que ha contribuido, junto con las medidas de campo, a la mejora en la descripción de los patrones de variabilidad estacional de la corriente, permitiendo analizar el efecto de la circulación en la dispersión de contaminantes.

Palabras clave: hidrodinámica marina, medidas de campo, modelización, contaminación, dispersión.

\section{INTRODUCTION}

In any coastal area, the offshore currents are related to superimposition between the prevailing oceanic current (at a large spatial and time scale), tidal currents, wind-induced currents and, inside the surf zone, currents generated by waves breaking. Water movement in the Cantabrian Sea, southern 


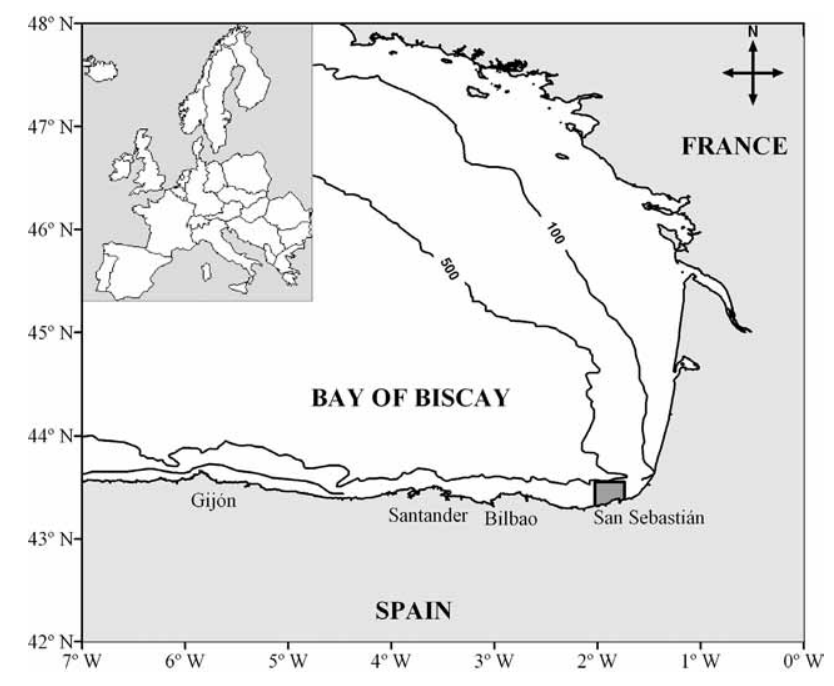

FIG. 1. - The location of the study area and the coastal section, between San Sebastian and Hondarribia (indicated with a rectangle). Note: bathymetry in metres.

Bay of Biscay, is not well understood. Furthermore, the general description of marine currents in the Basque region is almost exclusively confined to those in the surface waters (Ibáñez, 1979). A brief description of the present knowledge on major hydroclimatic agents in the Basque region-mainly wind forcing and hydrodynamics - is provided below.

The location of the coastal and continental shelf area under investigation is shown in Figure 1. The area is delimited to the west by a northerly transect in front of San Sebastián, and to the east by a transect (out to $100 \mathrm{~m}$ ) offshore of Cape Higer. In general, the area extends out to a water depth of around $100 \mathrm{~m}$.

In this particular area the anthropogenic pressure on the coastline is higher than the average for the Spanish Cantabrian coast. This factor, associated with the location of the region within the southern Bay of Biscay (on the international border with France), explains the need to understand the transport mechanisms associated with terrestrial pollutants, or those discharged accidentally from ships within this sensitive area (González et al., 2004).

Figure 2 shows the mooring positions of the selfrecording current meters $(\mathrm{SS}=\mathrm{San}$ Sebastián, $\mathrm{HO}=$ Hondarribia), together with the monthly hydrographical stations (D) and sedimentological sampling stations.

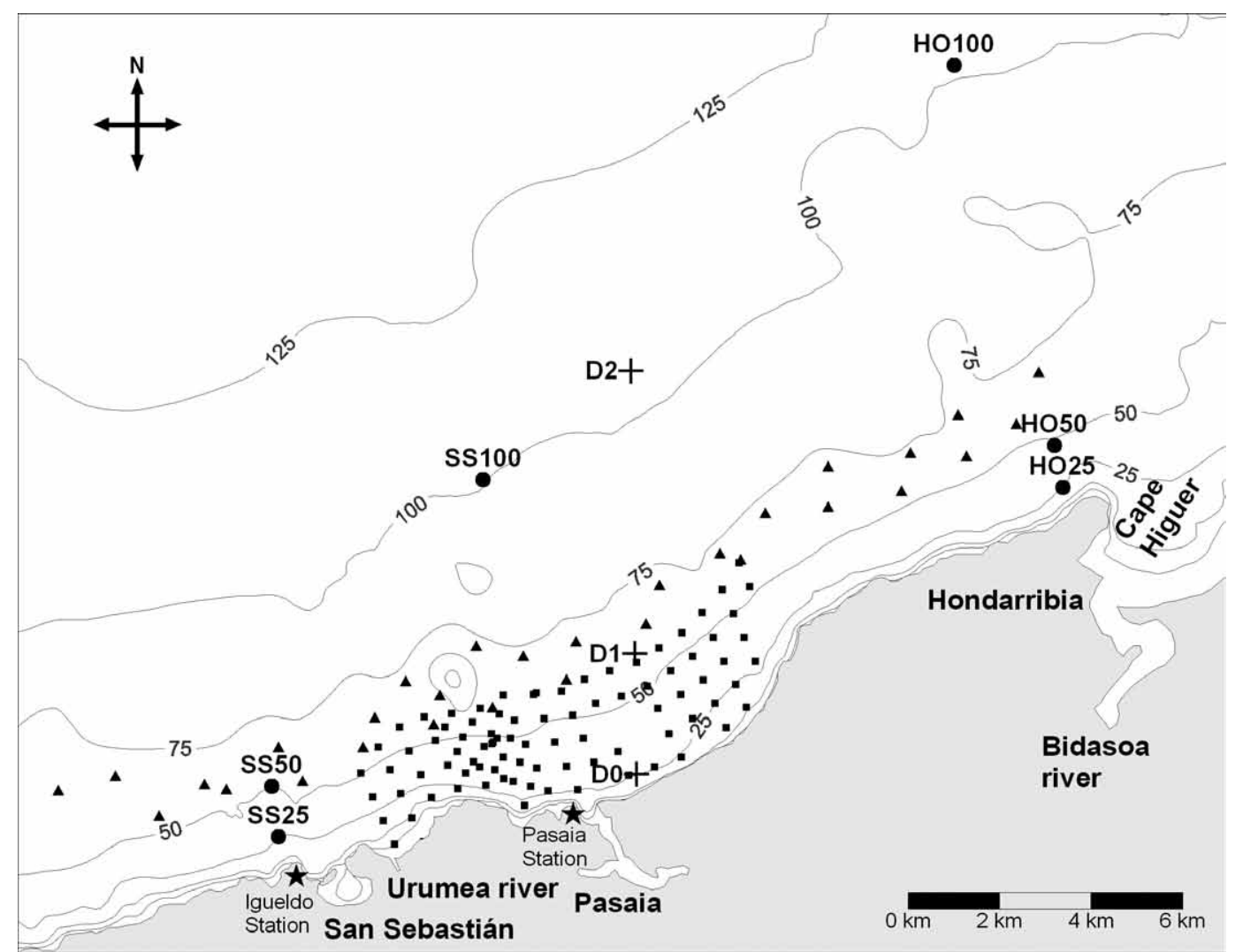

FIG. 2. - Map showing the location of the current meter moorings (black circles), hydrographical stations (crosses), seabed sediment sampling locations in 1999 (squares) and 2001 (triangles), and meteorological stations (stars). Note: bathymetry in metres. 
The astronomical tide is one of the mechanisms for generating currents in the region; it is semidiurnal, penetrating from the southwest into the Bay (Fig. 2). The effect of the tides (around $1.5 \mathrm{~m}$ at neap tides and $4 \mathrm{~m}$ at springs tides) on the sea surface oscillations is greater here than that of the atmospheric pressure (order of centimetres) or the wind effect, showing differences of orders of magnitude in the forcing mechanisms (Gonzalez et al., 2002, 2004).

Despite the importance of tidally-induced surface water fluctuations, the contribution of the tides to the generation of currents is more modest (except in the estuaries) in the area than that of the windinduced currents. In situ measurements, together with the output of several numerical models, have shown that the tidal current maxima decrease at increased water depths. At the same water depth and towards the north (near the French coast), the tidal current velocity increases (Álvarez et al., 1998).

The net drift in the tidal currents is known as the residual (tidal) current; it is caused by non-linear interactions between the harmonic components. The effect of this current is minimal along the Basque coast, increasing towards the north and west of the Bay of Biscay (González et al., 2004).

An important general controlling factor on the marine currents is the tangential stress exerted on the sea surface by the wind. The orientation of the coastline (east-west along the Spanish coast and north-south along the French coast), together with the seasonal distribution of the dominant winds, explains (to a large extent) the general drift of the surface water masses. Winds blow mainly from the southwest in autumn and winter, generating currents that, on average, cause drift towards the east and north. The wind pattern changes towards the northwest during spring, causing currents to move in a southerly direction along the French coast, and towards the west-southwest along the Spanish coast. The summer situation is similar to that in spring, although the presence of weak winds of high variability means that the general drift direction of the currents is more indeterminate (Lazure, 1997).

The oceanographic processes in the Cantabrian shelf area are highly influenced by seasonallyinduced factors (Koutsikopoulos and Le Cann, 1996), and through the spring-summer period the central Cantabrian coast is characterised by upwelling processes that are considered to be an important mechanism of fertilisation of the photic layer. The prevailing eastern component of the wind stress, parallel to the coast during this period, causes upwelling. Subsequent cooling of the surface waters takes place, together with cross-shelf transport of the light surface waters away from the coast (Gil et al., 2002).

In general, northerly winds produce upwelling on the French coast, whereas easterly winds produce it on the Spanish coast (due to the change in coastal orientation). Since the Basque coast is a transitional region in which the coastal orientation changes (Borja et al., 1996), the annual cycle of the shelf waters of the Basque coast can be characterised by changes in the relative prevalence of the downwelling and upwelling mechanisms (Valencia et al., 2004). Thus, in autumn and winter southerly and westerly winds are prevalent in the SE corner of the Bay of Biscay, and their average speeds are the highest of the year (Usabiaga et al., 2004). This regime causes currents flowing to the north and east, and consequently the dominance of downwelling in the shelf waters of the Basque coast. In spring, the reduction of wind stress and the change of the wind direction, in response to the prevailing northwesterly winds, causes currents towards the west-southwest. This regime initiates the relaxation of downwelling and turbulence with some upwelling events (Valencia et al., 2004).

An overall complex pattern of water movements, in response to a number forcing mechanisms, is established over the Basque region. Therefore, a general description of the water circulation within the southeastern limit of the Bay of Biscay is required.

In addition to the development of the understanding of the oceanic circulation within the southeastern part of the Bay of Biscay, the effect of water circulation on the dispersion of pollutants requires investigation. Hence, the present study will attempt to fulfil both of the above requirements, undertaken on the basis of: (a) the analysis of field measurements; and (b) calibration and utilisation of a numerical model for predictive purposes.

\section{MATERIALS AND METHODS}

Current meters were deployed at 25, 50 and 110 $\mathrm{m}$ water depths along two transects (Fig. 2) over a period of 2 years (Table I). The moorings in the proximity of San Sebastian and Hondarribia are indicated with the acronym SS and $\mathrm{HO}$ respectively 
TABLE 1. - Location, deployment times and sampling rates for the current meters.

\begin{tabular}{|c|c|c|c|c|c|c|c|}
\hline $\begin{array}{l}\text { Mooring } \\
\text { reference }\end{array}$ & $\begin{array}{c}\text { Location (geographical } \\
\text { coordinates) }\end{array}$ & $\begin{array}{c}\text { Location } \\
\text { (UTM, in metres) }\end{array}$ & $\begin{array}{l}\text { Instruments } \\
\text { used }\end{array}$ & $\begin{array}{l}\text { Water depth } \\
\text { (m) }\end{array}$ & $\begin{array}{c}\text { Mean depth } \\
\text { below surface (m) }\end{array}$ & Record length & $\begin{array}{c}\text { Sampling rate } \\
\text { (minutes) }\end{array}$ \\
\hline SS 25 & $\begin{array}{l}43^{\circ} 19.8^{\prime} \mathrm{N} \text { lat. } \\
2^{\circ} 00.8^{\prime} \mathrm{W} \text { long. }\end{array}$ & $\begin{array}{c}x=579,994 \\
y=4,798,021\end{array}$ & DCM 12 & 27.5 & $\begin{array}{c}0,4,8,12,16 \\
\text { and } 20\end{array}$ & $\begin{array}{c}28 / 02-03 / 04 / 2000 \\
25 / 08-7 / 11 / 2000\end{array}$ & 30 \\
\hline SS 50 & $\begin{array}{l}43^{\circ} 20.4^{\prime} \mathrm{N} \text { lat. } \\
2^{\circ} 00.9^{\prime} \mathrm{W} \text { long. }\end{array}$ & $\begin{array}{c}x=579,845 \\
y=4,799,130\end{array}$ & DCM 12 & 48.2 & $\begin{array}{c}0,8,16,24,32 \\
\text { and } 40\end{array}$ & $\begin{array}{l}06 / 03 / 2000- \\
14 / 04 / 2001\end{array}$ & 30 \\
\hline SS 100 & $\begin{array}{l}43^{\circ} 24.0^{\prime} \mathrm{N} \text { lat. } \\
1^{\circ} 58.9^{\prime} \mathrm{W} \text { long. }\end{array}$ & $\begin{array}{c}x=584,466 \\
y=4,805,826\end{array}$ & $\begin{array}{c}\text { S4 } \\
\text { RCM } 7 \\
\text { S4 }\end{array}$ & 103 & $\begin{array}{l}20 \\
50 \\
90\end{array}$ & $\begin{array}{l}07 / 03 / 2000- \\
12 / 02 / 2001\end{array}$ & 30 \\
\hline HO 25 & $\begin{array}{l}43^{\circ} 23.8^{\prime} \mathrm{N} \text { lat. } \\
1^{\circ} 47.9^{\prime} \mathrm{W} \text { long. }\end{array}$ & $\begin{array}{c}x=597,318 \\
y=4,805,654\end{array}$ & DCM 12 & 36 & $\begin{array}{c}0,4,8,12,16 \\
\text { and } 20\end{array}$ & $\begin{array}{l}22 / 05-13 / 09 / 2001 \\
14 / 03-14 / 05 / 2002\end{array}$ & 30 \\
\hline HO 50 & $\begin{array}{l}43^{\circ} 24.3^{\prime} \mathrm{N} \text { lat. } \\
1^{\circ} 48.2^{\prime} \mathrm{W} \text { long. }\end{array}$ & $\begin{array}{c}x=596,953 \\
y=4,806,574\end{array}$ & DCM 12 & 48 & $\begin{array}{c}0,8,16,24,32 \\
\text { and } 40\end{array}$ & $\begin{array}{l}15 / 02 / 2001- \\
25 / 10 / 2001\end{array}$ & 30 \\
\hline HO 100 & $\begin{array}{l}43^{\circ} 28.8^{\prime} \mathrm{N} \text { lat. } \\
1^{\circ} 49.7^{\prime} \mathrm{W} \text { long. }\end{array}$ & $\begin{array}{c}x=594,759 \\
y=4,814,874\end{array}$ & $\begin{array}{l}\text { S4 } \\
\text { S4 } \\
\text { S4 }\end{array}$ & 102 & $\begin{array}{l}20 \\
50 \\
90\end{array}$ & $\begin{array}{l}26 / 02 / 2001-6 / 12 / 2001 \\
26 / 02 / 2001-20 / 3 / 2002 \\
26 / 02 / 2001-20 / 3 / 2002\end{array}$ & $\begin{array}{l}1 \\
2 \\
2\end{array}$ \\
\hline
\end{tabular}

(Fig. 2). At all 6 moorings, the current data sets were recorded by AANDERAA DCM-12 Doppler, S4 electromagnetic and RCM-7 mechanical current meters.

In addition, monthly hydrographical cruises were performed at stations D0, D1 and D2 to obtain vertical profiles of temperature, salinity, dissolved oxygen, fluorescence and light transmission. The horizontal and vertical fluctuations of the sea water density provide data sets for the calibration of the hydrodynamic model. Further, seabed sediment sampling locations are indicated, by triangles, in Figure 2. The samples, obtained with Van Veen and Box Corer dredge samplers, were sieved to obtain granulometric curves for the seabed material.

In order to analyse the sediment transport directions, the method proposed by McLaren and Bowles (1985) and modified by Gao and Collins (1991) was followed. The model is based upon comparison between one sample and adjacent samples to reach a conclusion on "transport vectors", considering some patterns characterising movements based on the granulometric parameters

For the hydrodynamic modelling, the TRIMODENA 3D finite element numerical model was applied. TRIMODENA was developed by the Laboratory of Marine Engineering (LIMBarcelona), together with AZTI, within the framework of the PACOS project of the EU- ESPRIT Programme. This particular software contains three modules that have been used in many projects for numerical hydrodynamic simulations (González et al., 1995) of dispersive processes (González et al., 1998) and marine pollution (Mader et al., 2001; González et al., 2004).

The current and water level simulations are performed using the following codes:

(a) ECADIS, which calculates density and windinduced currents (Espino, 1994); and

(b) MAREAS, which simulates the astronomical tidal propagation and estimates the currents and water levels induced (González, 1994).

ECADIS and MAREAS solve the Shallow Water Equations (SWE: Equations 1, 2 and 3) by means of the Finite Element Method (FEM) with quasi-3D approximations (Zienkiewicz and Heinrich, 1979). ECADIS (Espino, 1994) processes the stationary part of the SWE, using the macro-element technique and the penalty function (Fortin and Fortin, 1985). The MAREAS model (González, 1994) solves the tidal propagation equations, expressed as a sum of a finite series of harmonic constituents (Walters, 1986), using a horizontal Q1/P0 discretisation and vertical spectral decomposition.

\section{Continuity Equation:}

$$
\partial t \eta+\partial x[(\eta+h) U]+\partial y[(\eta+h) V]=0 .
$$

\section{Momemtum Equation:}

$$
\begin{gathered}
\partial_{t} u+u \partial_{x} u+v \partial_{y} u-f v=-g \frac{\rho_{0}}{\rho} \partial_{x} \eta-g \frac{1}{\rho} \partial_{x} \alpha \\
+\partial_{x}\left[2 K_{H}\left(\partial_{x} u\right)\right]+\partial_{y}\left[K_{H}\left(\partial_{x} v+\partial_{y} u\right)\right]+\partial_{z}\left[K_{z}\left(\partial_{z} u\right)\right] ;
\end{gathered}
$$




$$
\begin{gathered}
\partial_{t} v+u \partial_{x} v+v \partial_{y} v+f u=-g \frac{\rho_{0}}{\rho} \partial_{y} \eta-g \frac{1}{\rho} \partial_{y} \alpha \\
+\partial_{x}\left[K_{H}\left(\partial_{x} v+\partial_{y} u\right)\right]+\partial_{y}\left[2 K_{H}\left(\partial_{y} v\right)\right]+ \\
\partial_{z}\left[K_{z}\left(\partial_{z} v\right)\right],
\end{gathered}
$$

where:

$u, v$ are horizontal velocity components;

$U, V$ are vertically-averaged horizontal velocity components;

$\eta$ is the vertical displacement of the water surface;

$h$ is water depth;

$f$ is the Coriolis parameter;

$g$ is the acceleration due to gravity;

$\rho$ is sea water density and $\rho_{\mathrm{o}}$ is surface sea water density;

$a$ is sea water specific volume;

$K_{H}$ is the horizontal kinematic eddy diffusivity; and

$K_{z}$ is the vertical kinematic eddy diffusivity.

The convection-diffusion equation (Equation 4) is solved by means of the RECODE model (Hermosilla, 1996). RECODE also uses the quasi3D approximation and the FEM to solve the evolution of spills into the marine environment. To represent the temporal variation of the variables, RECODE uses a two-step Taylor-Galerkin algorithm, which is recommended for problems in which convection is dominant (Donnea, 1985). The code includes a sink/source coefficient for simulating temporal variations of the compound concentration, which makes it usable for a high variety of applications: soluble components, sedimentation particles, degradable products (such as hydrocarbons) under physical, chemical or biological actions, and organisms with mortality and reproduction rates.

$$
\begin{gathered}
\frac{\partial C}{\partial t}+\frac{\partial}{\partial x}(u C)+\frac{\partial}{\partial y}(v C)- \\
-\frac{\partial}{\partial x}\left(K_{x} \frac{\partial C}{\partial x}\right)-\frac{\partial}{\partial y}\left(K_{y} \frac{\partial C}{\partial y}\right)+S C=0
\end{gathered},
$$

where:

$C$ is the compound concentration $\left(\mathrm{kg} \mathrm{m}^{-2}\right)$;

$u, v$ are the horizontal velocity components $\left(\mathrm{m} \mathrm{s}^{-1}\right)$;

$K_{x}, K_{y}$ are the horizontal dispersion coefficients $\left(\mathrm{m}^{-2} \mathrm{~s}^{-1}\right)$; and

$S$ is the sink/source coefficient.

The numerical mesh used for hydrodynamic simulations is shown in Figure 3. The average meshsize is about $190 \mathrm{~m}$. For the dispersion model, a denser mesh (average size of about $50 \mathrm{~m}$ ) is applied.

The objective of the dispersion modelling is to simulate the behaviour of a spill from a submarine outflow or floating waste lines. These spills have a characteristic size of several tens of metres, which is

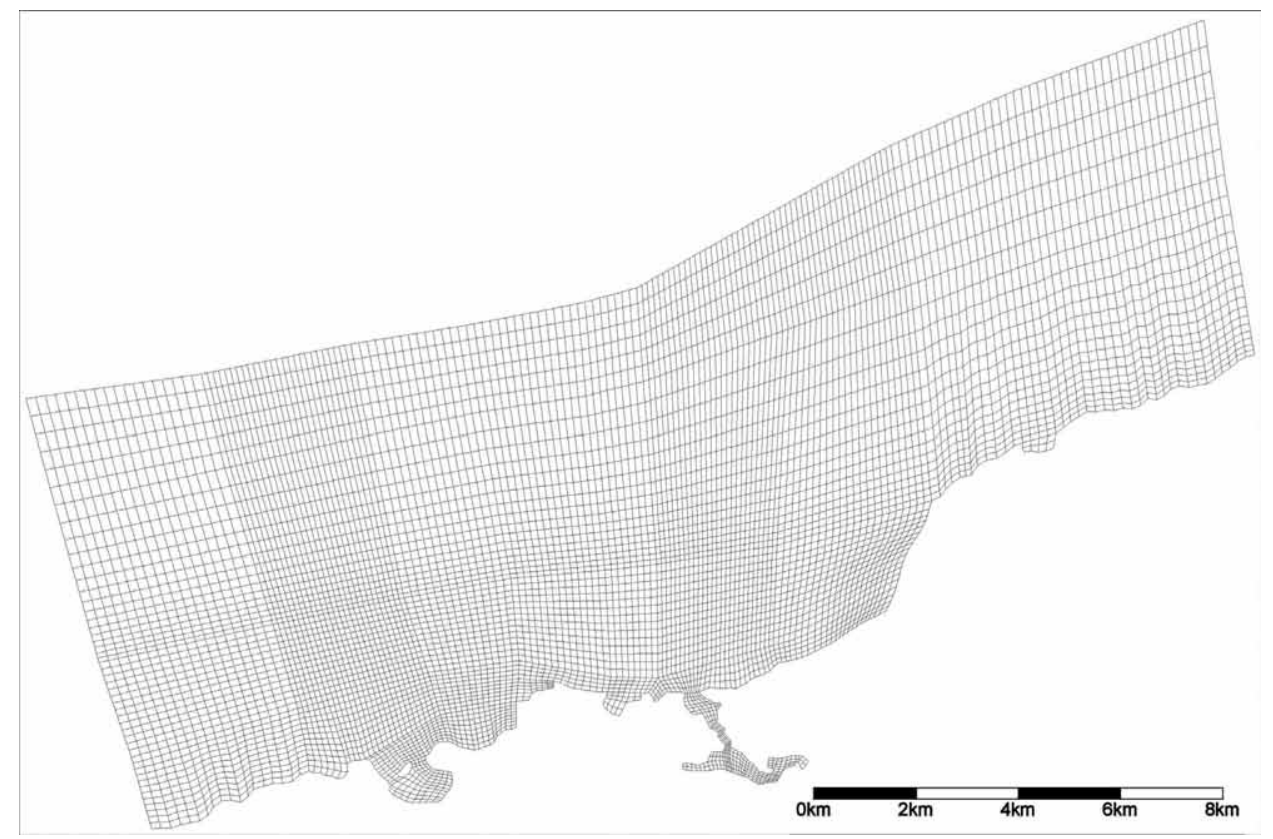

FIG. 3. - Numerical mesh of discretisation for the hydrodynamic modelling. 


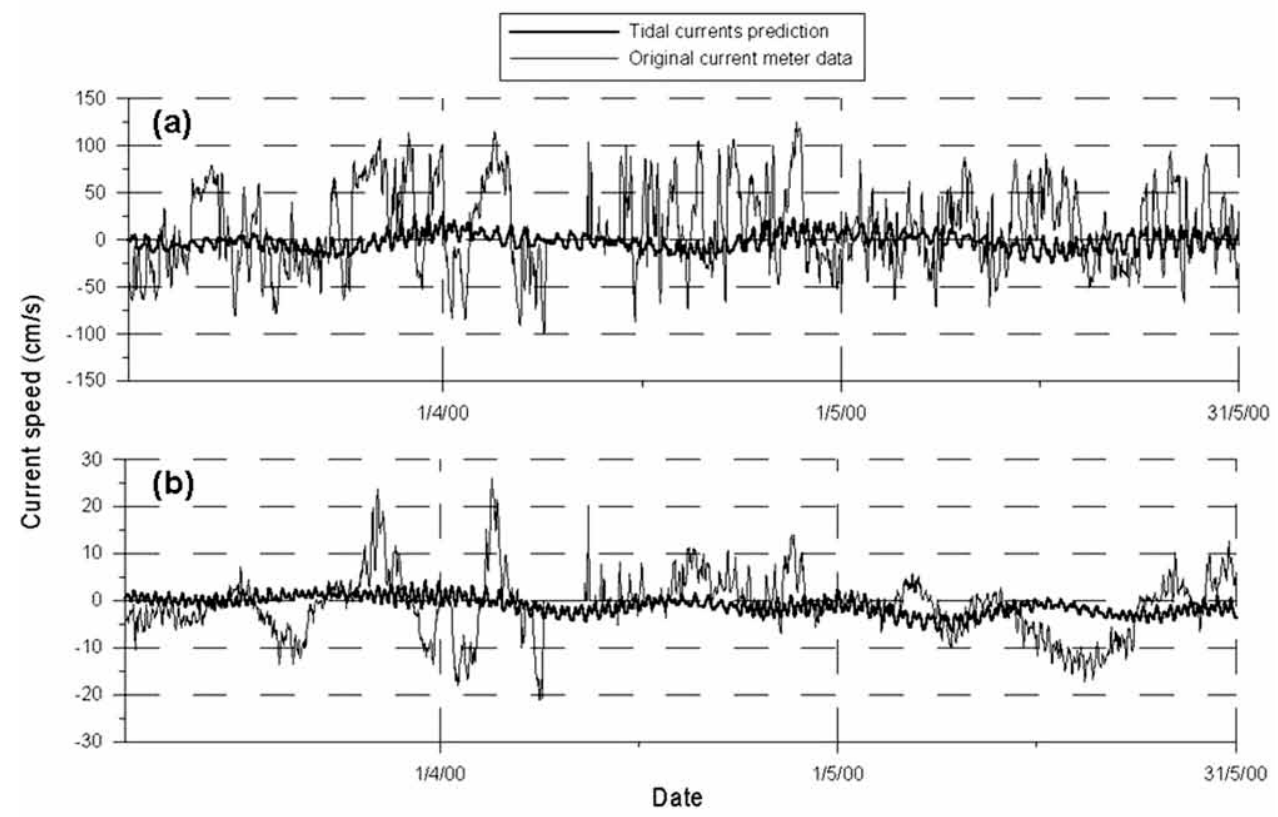

FIG. 4. - Examples of records of the easterly current component (measured) and the tidal current (predicted) at location SS50: (a) at the surface, and (b) at $40 \mathrm{~m}$ depth. Note: tidal current predictions are based upon raw current data. For locations, see Figure 2 (from González et al., 2004).

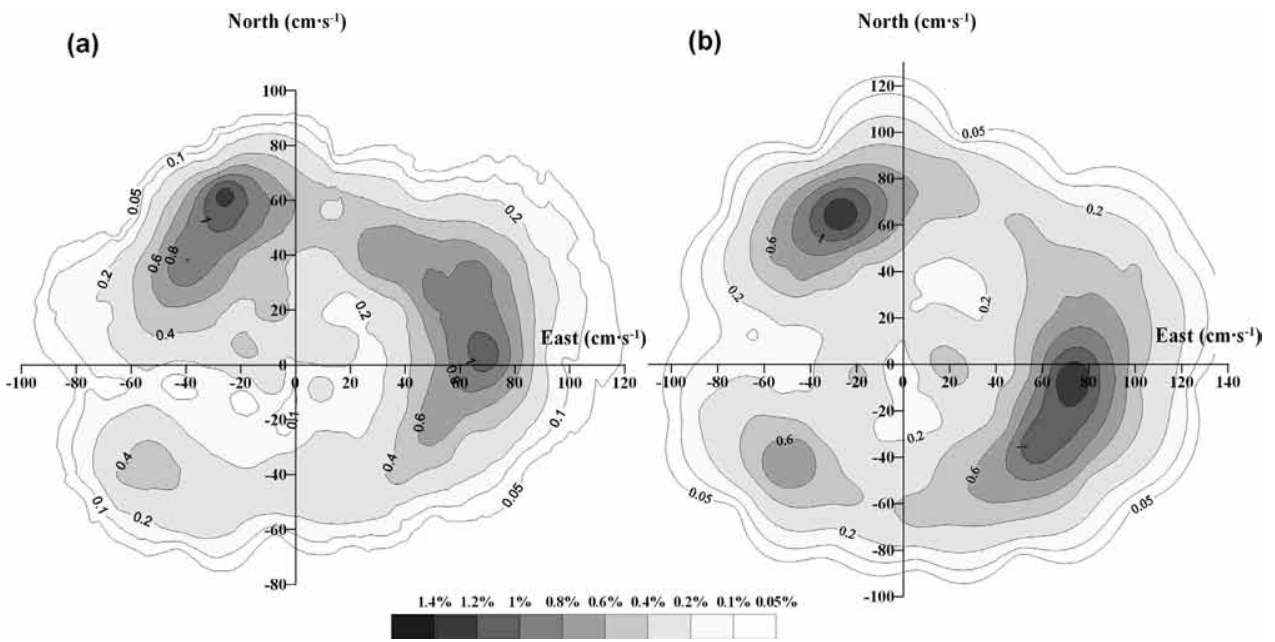

FIG. 5. - Interpolated distribution of all raw surface current data measured in spring 2000 at location SS25 (a) and location SS50 (b). For locations, see Figure 2.

lower than the scale of variations of the simulated current velocity. Thus, for the dispersion modelling a finer mesh was used with interpolated current velocity data.

\section{RESULTS}

\section{Marine dynamics}

Tidal currents are predominant near the mouths of the estuaries. However, wind-induced currents become more important in the open sea, particularly within the upper layers of the water column. For example, at stations offshore of San Sebastián, the predicted maximum surface tidal speed is around $30 \mathrm{~cm} \mathrm{~s}^{-1}$, which is considerably lower than the overall maximum measured speed of around $1.3 \mathrm{~m} \mathrm{~s}^{-1}$ (SS50) (Fig. 4). With increasing depth within the water column, the wind-induced current also diminishes.

The distribution of surface currents (total currents, consisting of wind and tidal contributions), as measured at SS25 and SS50 during spring 2000, is shown in Figure 5. The current distributions are sim- 


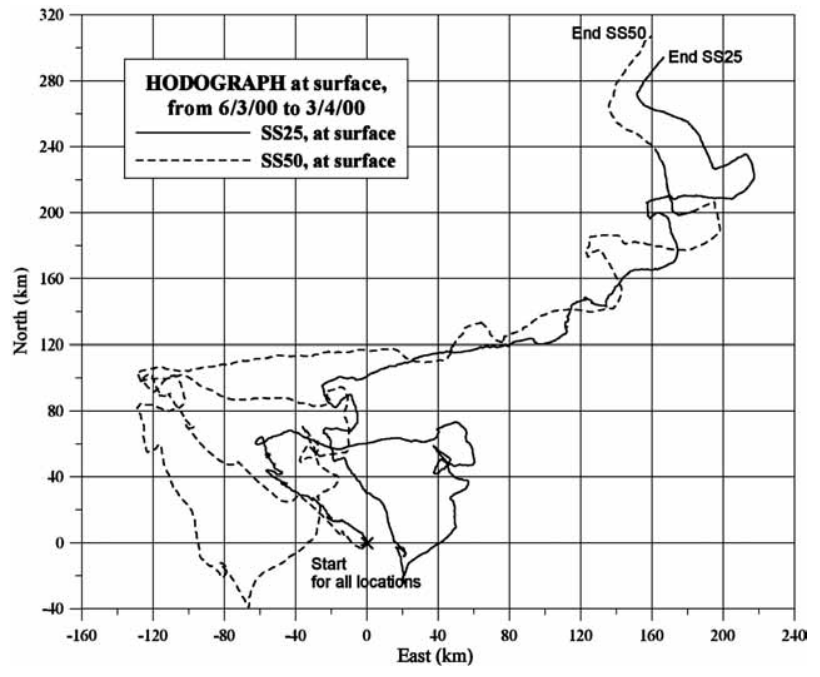

FIG. 6. - Progressive vectors derived on the basis of measurements obtained at the SS25 and SS50 moorings between 6/3/00 and 3/4/00 in the surface waters. For locations, see Figure 2.

ilar in terms of direction. The most frequent directions are towards the north-northwest and the east. In addition, statistical analysis shows that maximum surface velocities are slightly higher at a water depth of $50 \mathrm{~m}$ (SS50) than at $25 \mathrm{~m}$ (SS25). In addition, progressive vectors (or hodographs) of the surface currents from the SS25 and SS50 moorings in spring 2000 are shown in Figure 6. The progressive vector plots show that the net drift of the surface currents is similar, in terms of displacement, for both the SS25 and SS50 moorings.

This similarity extends down to a water depth of about $20 \mathrm{~m}$ (below the surface). However, at $100 \mathrm{~m}$ water depth (SS100) the behaviour of the currents farther offshore is substantially different, due to a reduced effect of the geographical setting. As an example of the variability in the horizontal distribution of currents, the progressive vectors are presented in Figure 7. These were calculated on the basis of currents measured at a water depth of approximately $20 \mathrm{~m}$ below the surface at the SS25, SS50 and SS100 moorings in spring 2000. The net drift of the currents related to the SS25 and SS50 moorings is similar and towards the southwest. However, the SS100 mooring shows high variability in displacement and net drift towards the northeast.

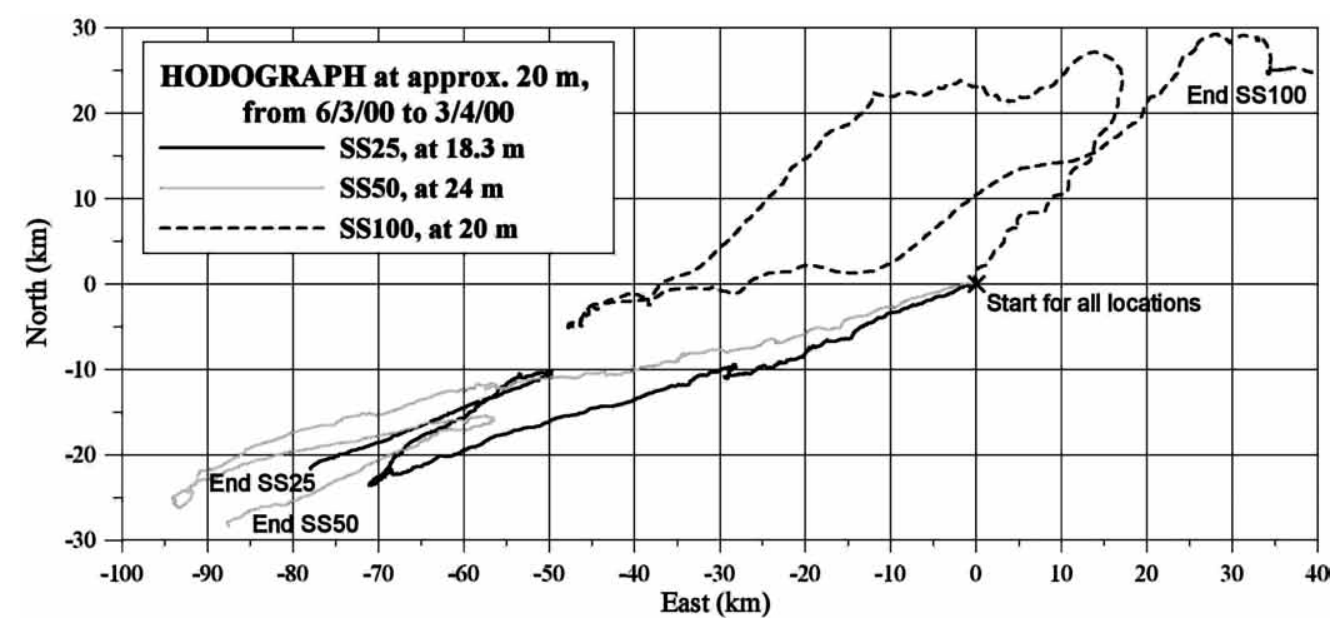

FIG. 7. - Progressive vectors for an approximately $20 \mathrm{~m}$ depth (below the surface), derived on the basis of measurements obtained at the SS25, SS50 and SS100 moorings between 6/3/00 and 14/4/00. For locations, see Figure 2.

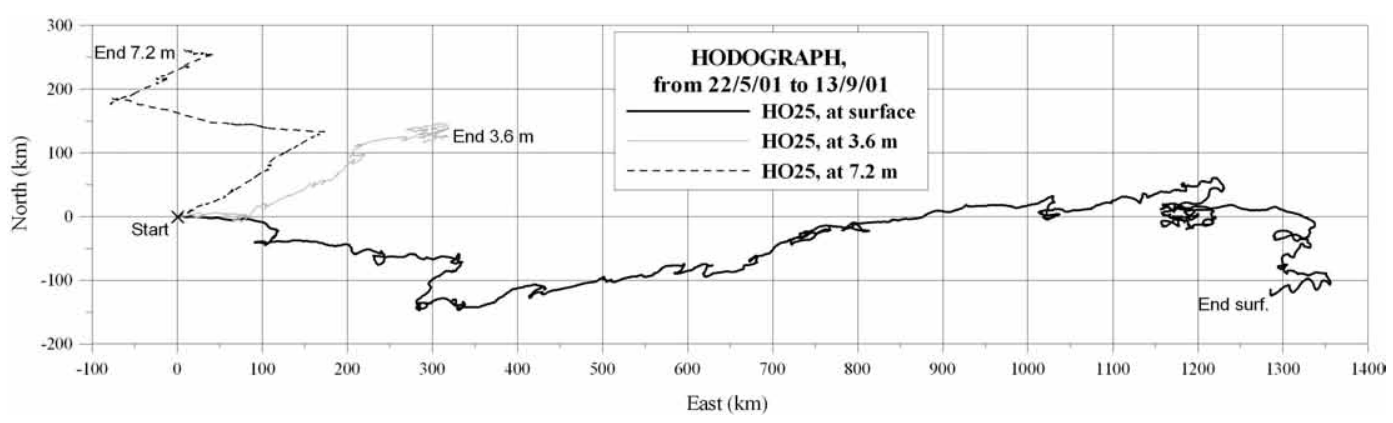

FIG. 8. - Progressive vectors calculated from the measurements obtained at the HO25 mooring between 22/5/01 and 13/9/01 in the surface and at 3.6 and $7.2 \mathrm{~m}$ depths (below the surface). For locations, see Figure 2. 
58 - A. FONTÁN et al.

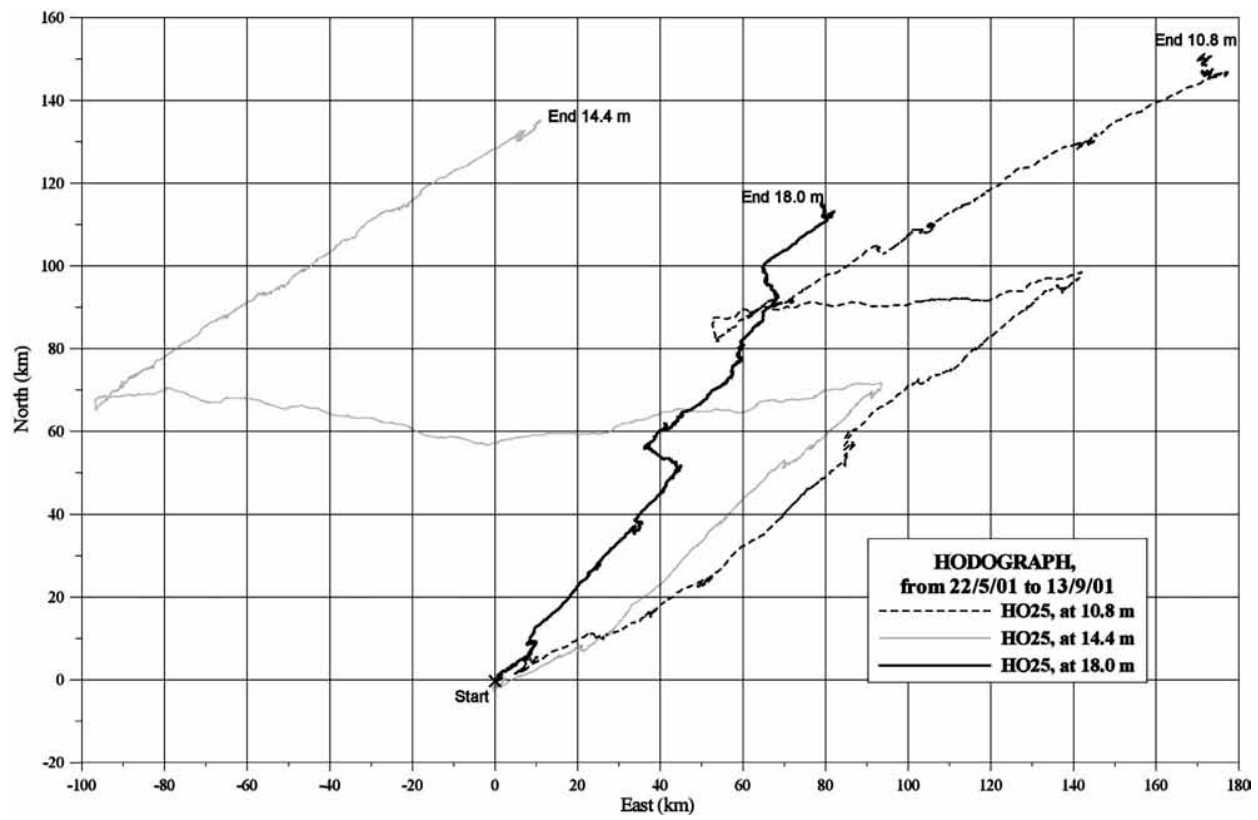

FIG. 9. - Progressive vectors calculated from the measurements obtained at the HO25 mooring between 22/5/01 and 13/9/01 at 10.8, 14.4 and $18 \mathrm{~m}$ depth (below the surface). For locations, see Figure 2.

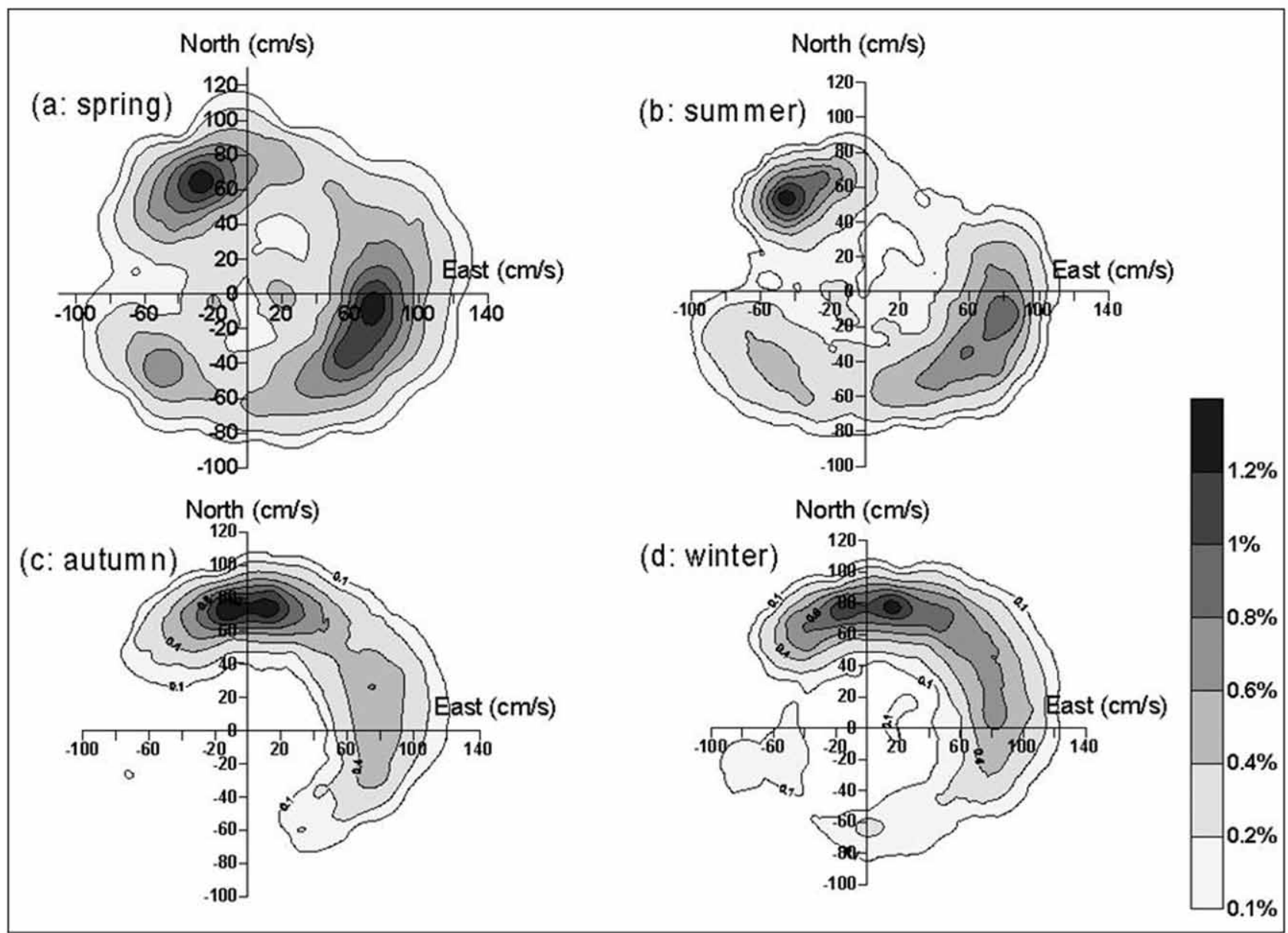

FIG. 10. - Seasonal distribution of the surface total currents measured at location SS50: (a) spring 2000; (b) summer 2000; (c) autumn 2000; and (d) winter 2001. For station locations, see Figure 2 (from González et al., 2004). 
As an example of the vertical variability in the currents, Figure 8 shows the progressive vectors derived from measurements collected at $\mathrm{HO} 25$ at the surface, 3.6 and $7.2 \mathrm{~m}$ water depths. Net displacement is towards the east at the surface, and towards the northeast at $3.6 \mathrm{~m}$ depth. From $7.2 \mathrm{~m}$ down to about $18.0 \mathrm{~m}$ depth (Figs. 8 and 9) the currents show a similar behaviour, with net drift towards the northeast at the beginning and then towards the west and northeast, although this behaviour is less marked at $18.0 \mathrm{~m}$ depth.

As an example of seasonal variability in the currents, the distribution of surface currents (total currents, consisting of wind and tidal contributions), as measured at SS50 between spring 2000 and winter 2001, is shown in Figure 10.

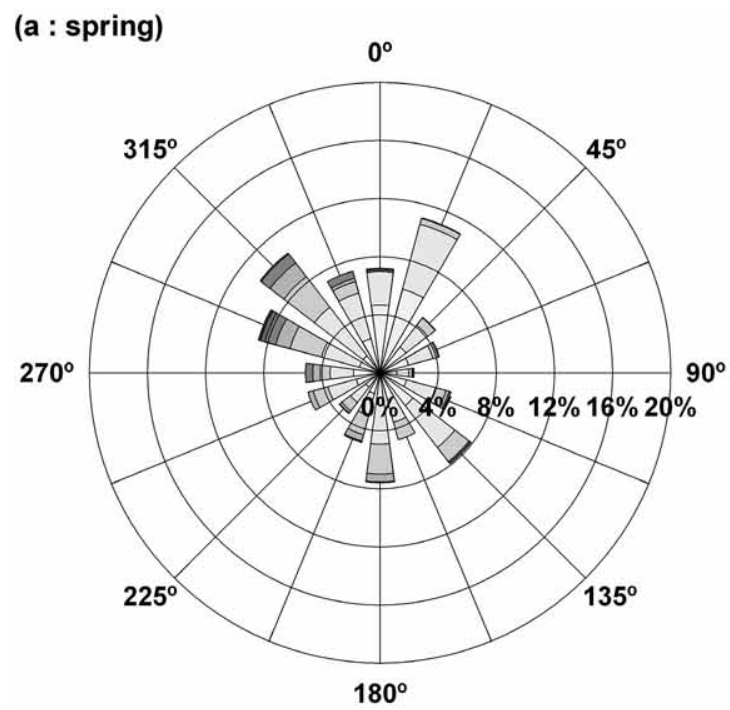

(c : autumn)

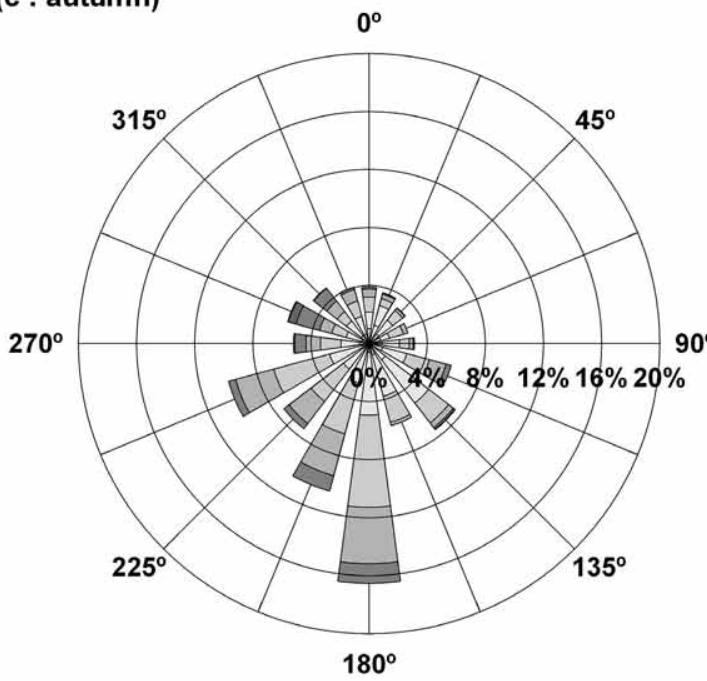

Two different patterns of surface water circulation related to meteorological conditions recorded at the Pasaia station can be identified (Fig. 11; for station locations, see Fig. 2). The winds blow mainly from the northwest and southwest in spring and summer (Fig. 11a and b); these cause currents towards the eastwards and to the north-northwest (Fig. 10a and b). In autumn and winter, the winds blow from the south (Fig. 11c and d), causing northerly-directed currents (Fig. 10c and d), and are in agreement with the meteorological conditions at Pasaia.

\section{Sediment transport}

In 2001 surficial bed sediment samples were collected over a coastal section (between 40 and $75 \mathrm{~m}$ (b: summer)

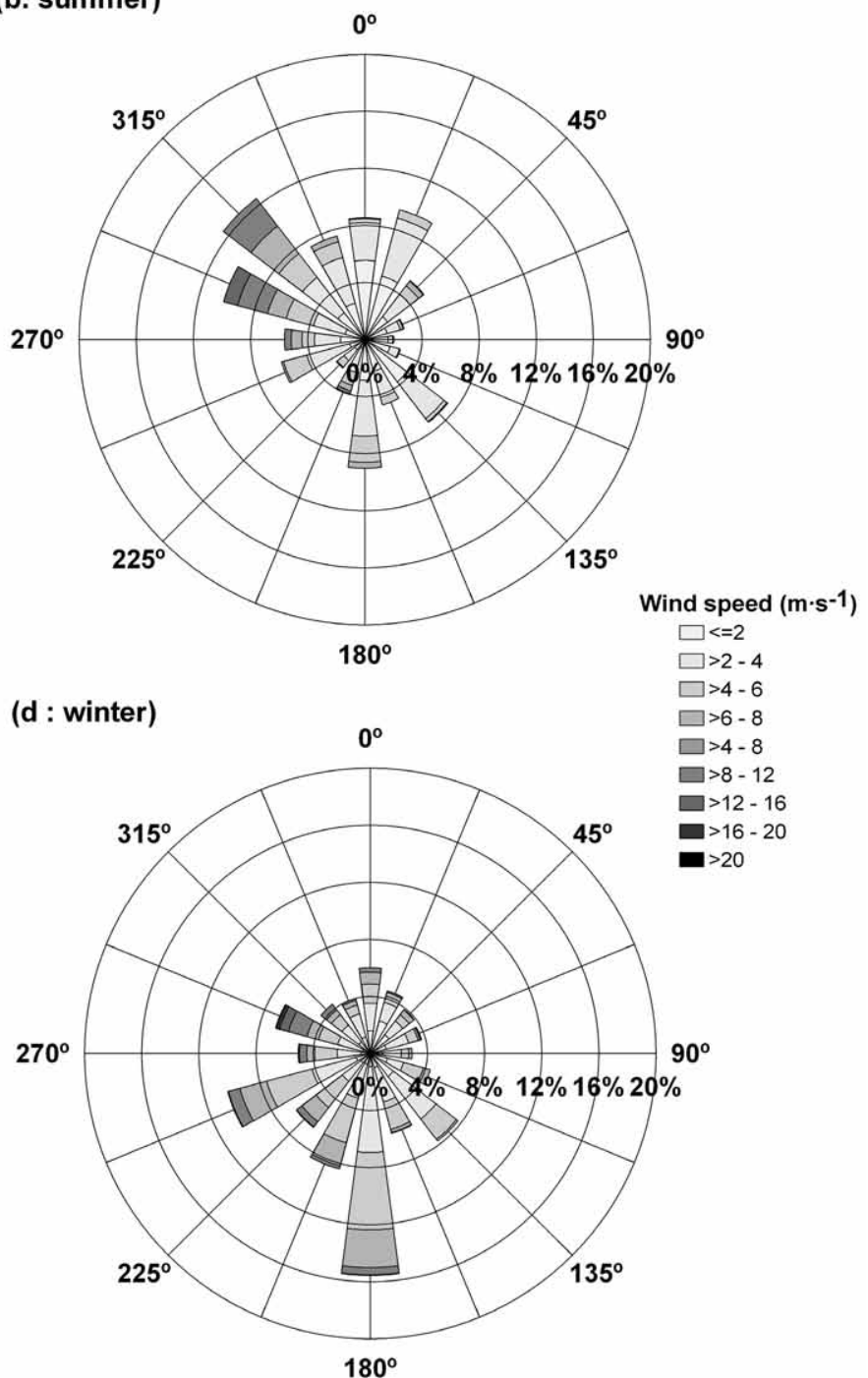

FIG. 11. - Seasonal distribution of the wind measured at the Meteorological Station of Pasaia (www.puertos.es): (a) spring 2000; (b) summer 2000; (c) autumn 2000; and (d) winter 2001. For station location, see Figure 2. 


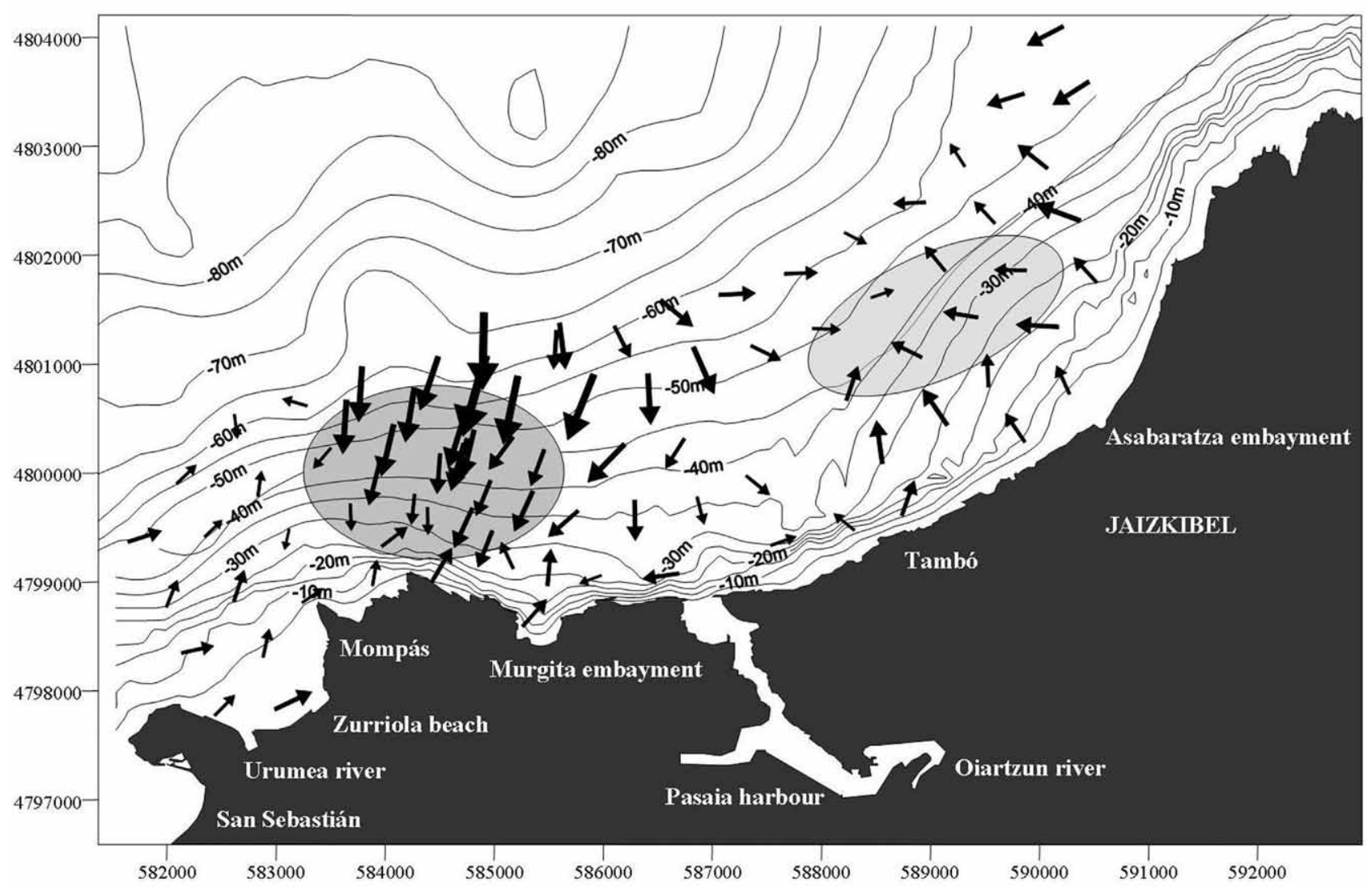

FIG. 12. - Sediment transport pathways over the study area according to the McLaren (sediment transport) approach, modified by Gao and Collins (1991). Note: bathymetry in metres (from Uriarte et al., 2004).

in depth) at the San Sebastian and Hondarribia transects. The main aim was to establish the sedimentological characterisation of the area; this was undertaken in the coastal area incorporating the Urumea River mouth and Asabaratza embayment in 1999. Figure 2 shows the locations of the sedimentological sampling stations in 1999 and 2001.

The results obtained from the trend analysis of McLaren, modified by Gao and Collins (1991), are represented in Figure 12. The vectors indicate the possible direction of sediment transport, whilst the magnitude expresses the probability of transport in this direction. Two accumulation zones were identified. The first area, offshore of Cape Mompás, consists of: mud derived from the Mompás submarine outflow; river and wastewater discharges in Pasaia Bay; and Pasaia Harbour dredging material disposal. The second area is related to the sandy area offshore of Jaizkibel Cliffs, between Cape Tambó and Asabaratza embayment. From here, some 1.1 million cubic metres of sand were extracted to nourish Zurriola beach (San Sebastián). Monitoring studies of this beach have shown that it slowly loses the added materials towards the Urumea River mouth area and towards the east.
Statistical analysis undertaken for the first zone of accumulation shows the presence of sandy material that originates from the Zurriola beach and is transported towards the Asabaratza embayment area of accumulation. This transport could have occurred during stormy periods which induced a displacement towards the north. The north-eastward deep currents, measured in winter, were favourable for this pattern of movement.

It should be noted that the results of the McLaren model represent a particular situation: they are an instantaneous representation of the instant when the area was sampled. Consequently, stormy weather could change the sea bed characteristics (granulometry and bathymetry) and the associated transport results.

\section{Numerical modelling}

Marine hydrodynamics were modelled by means of the TRIMODENA model. Wind stress and tidally-induced currents associated with different hydrographical and meteorological scenarios were taken into account for this purpose. 


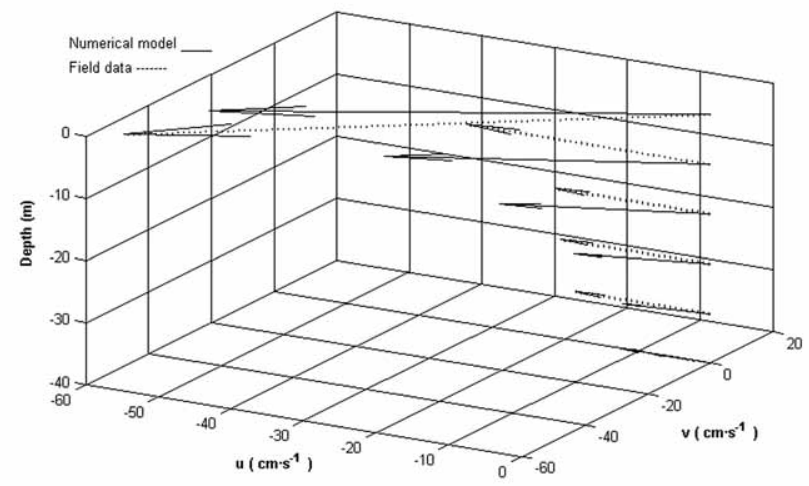

FIG. 13. - Comparison between hydrodynamic simulation and field data at the SS50 mooring, considering a northeasterly wind of about $20 \mathrm{~km} \cdot \mathrm{h}^{-1}$ ( $v$, north-south component, with north aligned along the positive y-axis; and $u$, east-west component, with east aligned along the positive $\mathrm{X}$-axis).

Different scenarios, in terms of wind intensity and direction, were established by means of the analysis of wind data records from Igueldo (National Institute of Meteorology, San Sebastián) (see Fig. 2 for location). Thus, the ECADIS numerical model results were calibrated through the analysis of wind and current meter data records. Within this context, Figure 13 shows the comparison between the results from the hydrodynamic modelling (northeasterly wind conditions) and data obtained from the current meter located at $50 \mathrm{~m}$ depth, offshore of San Sebastian. Overall, a good agreement between simulated and recorded data was obtained for the calibration process.

Previously obtained results related to the astronomical tide were used to determine the open sea boundary conditions for the vertical displacement of the water surface (González et al., 2001). Non-linear bottom friction and turbulent diffusivity coefficients were determined by means of an approach which minimises differences between the model results and the field data.

These results were used to develop a numerical tool for analysing dispersion and pollution processes over the study area. The RECODE model was used for this purpose. Floating debris dispersion after 24 hours of simulation with the RECODE model is shown in Figure 14. The source area was located at the end of the submarine outflow of Mompás. For this particular simulation, a northeasterly wind of about $20 \mathrm{~km} \mathrm{~h}^{-1}$ was considered, this being an unfavourable case for impact on the beaches of San Sebastian. The results are expressed in terms of percentage of the maximum concentration at the source area.

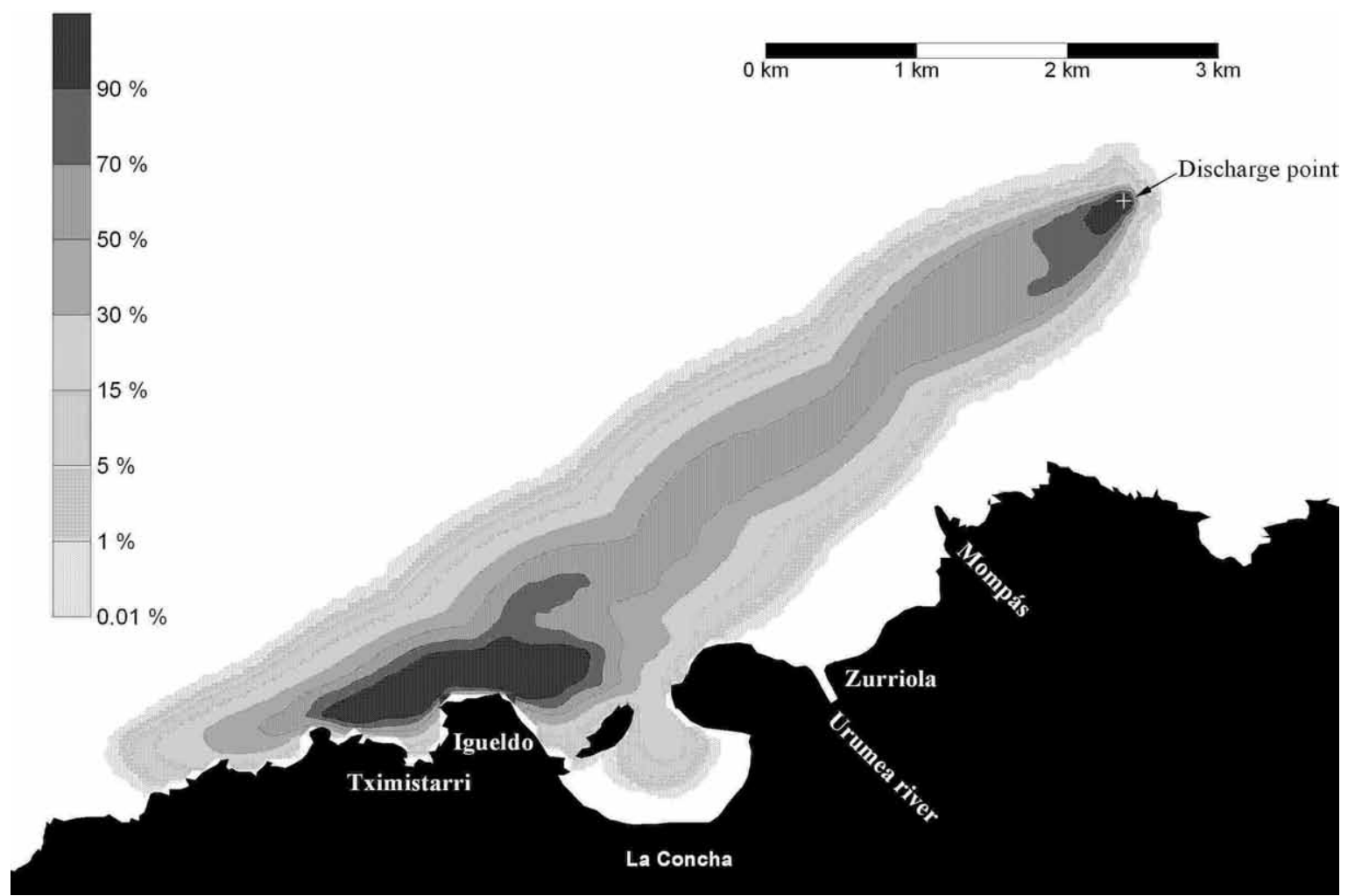

FIG. 14. - The evolution of the dumping of floating debris after 24 hours of simulation near San Sebastián (expressed in \% of the concentration, from continuous dumping at the discharge point). 


\section{CONCLUSIONS}

In general, the contribution of tides to the generation of currents is more modest in the area than that of wind For example, the predicted maximum surface tidal speed is considerably lower than the overall maximum measured speed at the SS50 mooring.

The surface currents at 25 and $50 \mathrm{~m}$ water depth show a similar pattern, which extends to a depth of about $20 \mathrm{~m}$. However, offshore the hydrodynamic pattern is significantly different due to a lesser effect of the geographical setting, as shown by comparison between data from the SS25 and SS50 moorings and those from the SS100 mooring.

From the coastline to the $50 \mathrm{~m}$ isobath, a threelevel hydrodynamic structure can be observed. A near-surface layer, down to a depth of about $4 \mathrm{~m}$, is influenced directly by the wind. An intermediate level, which extends from $4 \mathrm{~m}$ to a depth of about 15 $\mathrm{m}$, for the $25 \mathrm{~m}$ depth moorings, is characterised by lower net transport and variability than within the surface layer. Finally, at a deeper level close to the sea bottom, oscillating currents (parallel to the bathymetric contours) are identified.

The distribution of surface currents between spring 2000 and winter 2001, as measured at SS50, shows that the seasonal behaviour of the surface currents is mainly related to the most frequent wind conditions. In spring and summer the most frequent current directions are eastwards and towards the north-northwest, whereas in autumn and winter the current is principally northerly-directed.

Within the context of sediment transport at the seabed, the Gao and Collins (1991) sediment transport modelling identified two zones of accumulation between Cape Higuer and Cape Mompás: (a) a zone offshore of Cape Mompás; and (b) the sandbar between Cape Tambó and the Asabaratza embayment.

The hydrodynamic simulations obtained by numerical modelling and calibrated with current meter data have improved the knowledge of the physical processes that induce currents and the transport of particles and floating debris within the study area. Surface water circulation patterns have been reproduced, considering the wind stress predominant factor in relation to tidal effect (see above).

The dispersion of floating debris affects this coastal area, especially during summer, because of the interactions induced by the use of the beaches for leisure activities. However, major events may be related to high river discharges with heavy rainfall, particularly in spring or autumn.

It is difficult to obtain a representative simulation of floating debris dispersion in summer conditions because of (i) the difficulty in exactly identifying the discharge sources along an extensively exploited coast, and (ii) the lightness of the wind pattern during this period, and its high spatial variability due to the coastal topography. However, the main scenarios for the arrival of floating debris at the San Sebastian beaches, associated with north and north-easterly light breezes, were reproduced effectively by means of the numerical modelling.

The hydrodynamics of the Basque region appear to be complex. In addition, there is a lack of available knowledge on the marine currents. Consequently, a detailed analysis of the long-term data sets is required in order to separate the observed currents into specific process components in order to determine the relative importance of each process within the overall water circulation in the region.

\section{ACKNOWLEDGEMENTS}

This work was carried out with financial support from the Department of Public Works (Diputación Foral de Gipuzkoa, Spain), within the framework of the project entitled "Estudio de la dinámica marina y del medio físico de la costa comprendida entre Donostia-San Sebastián y Baiona", an extensive project monitoring marine dynamics (González et al., 2002). The meteorological data were obtained from the Observatory of San Sebastián (Instituto Nacional de Meteorología) and from the Pasaia Station (Puertos del Estado, www.puertos.es). We are very grateful to the sampling staff of the Marine Research Division (AZTI Foundation) for the high quality of the work performed.

\section{REFERENCES}

Álvarez, E., B. Pérez, J.C. Carretero and I. Rodríguez. - 1998. Tide and surge dynamics along the Iberian Atlantic coast. Oceanol. Acta, 21: 131-143.

Borja, Á., A. Uriarte, V. Valencia, L. Motos, and Ad. Uriarte. 1996. Relationships between anchovy (Engraulis encrasicholus) recruitment and the environment in the Bay of Biscay. Sci. Mar., 60 (Suppl. 2): 179-192.

Donnea, J. - 1985. A Taylor-Galerkin method for convective transport problems. Int. J. Numer. Meth. Eng., 20: 817-845.

Espino, M. - 1994. Estabilización de la superficie libre en la solución de ecuaciones de Shallow-Water por Elementos Finitos. Aplicaciones oceanográficas. Ph. D. thesis, Universitat 
Politècnica de Catalunya, Barcelona.

Fortin, M. and A. Fortin. - 1985. A generalization of Uzawa's Algorithm for the solution of the Navier-Stokes Equations. Comm. Appl. Numer. Meth., 1: 205-208.

Gao, S. and M.B. Collins. - 1991. A critique of the McLaren method for defining sediment transport paths-discussion. $J$. Sed. Petrol., 61: 143-146.

Gil, J., L. Valdés, M. Moral, R. Sánchez and C. García-Soto. 2002. Mesoescale variability in a high-resolution grid in the Cantabrian Sea (southern Bay of Biscay), May 1995. Deep-Sea Res. I, 49: 1591-1607.

González, M. - 1994. Un modelo numérico en Elementos Finitos para la corriente inducida por la marea. Aplicaciones al Estrecho de Gibraltar. First degree dissertation, Univ. Politecn. Catalunya.

González, M., M.A. García, M. Espino and A. S.- Arcilla. - 1995. Un modelo numérico en Elementos Finitos para la corriente inducida por la marea. Aplicaciones al Estrecho de Gibraltar. Rev. Int. Métodos Numér. Cálc. Diseño Ing., 11: 383-400.

González, M., Ad. Uriarte, L. Motos, Á. Borja and A. Uriarte. 1998. Validation of a numerical model for the study of anchovy recruitment in the Bay of Biscay. Oceans'98 IEEE-OES, Nice, 3: 1313-1318.

González, M., J. Mader, P. Gyssels, Ad. Uriarte and S. Sorhouet. 2001. Estudio numérico de propagación de la marea astronómica en el Golfo de Vizcaya. VI Congreso de Ingeniería de Puertos y Costas de España. Palma de Mallorca, 97-98.

González, M., P. Gyssels, J. Mader, A. Fontán, A. Del Campo and A.D. Uriarte. - 2002. Estudio de la dinámica marina y del medio físico de la costa comprendida entre Donostia-San Sebastián y Baiona. Diputación Foral de Guipúzcoa. Unpublished Report.

González, M, Ad. Uriarte, A. Fontán, J. Mader and P. Gyssels. 2004. Marine dynamics. In: A. Borja and M. Collins (eds.), Oceanography and Marine Environment of the Basque Country, Elsevier Oceanography Series, 70: 27-50. Amsterdam.

Hermosilla, F. - 1996. Estudio de la dispersión de contaminantes en el mar mediante el M.E.F. First degree dissertation,
Universitat Politècnica de Catalunya, Barcelona.

Ibáñez, M. - 1979. Hydrological studies and surface currents in the coastal area of the Bay of Biscay. Lurralde, 2: 37-75.

Koutsikopoulos, C. and B. Le Cann. - 1996. Physical processes and hydrological structures related to the Bay of Biscay anchovy. Sci. Mar., 60 (Suppl. 2): 9-19.

Lazure, M.P. - 1997. La circulation des eaux dans le Golfe de Gascogne. $10^{\text {émes }}$ rencontres interregionales de l'AGLIA. Saint Jean de Luz, 83-88.

Mader, J., M. González, V. Valencia, M. Espino, M. Hernáez, A. D. Uriarte and E. Comerma. - 2001. Elaboración de un modelo de simulación de la dispersión de hidrocarburos en el puerto de Bilbao. Medidas de campo. VI Congreso de Ingeniería de Puertos y Costas de España. Palma de Mallorca, 135-137.

McLaren, P. and D. Bowles. - 1985. The effects of sediment transport on grain-size distributions. J. Sed. Petrol., 55: 457-470.

Uriarte, Ad., M. Collins, A. Cearreta, J. Bald and G. Evans. - 2004. Sediment supply, transport and deposition: contemporary and Late Quaternary evolution. In: A. Borja and M. Collins (eds.), Oceanography and Marine Environment of the Basque Country, Elsevier Oceanography Series, 70: 75-95, Amsterdam.

Usabiaga, J.I., J. Sáenz, V. Valencia and Á. Borja. - 2004. Climate and Meteorology: variability and its influence on the Ocean. In: A. Borja and M. Collins (eds.), Oceanography and Marine Environment of the Basque Country, Elsevier Oceanography Series, 70: 75-95, Amsterdam.

Valencia, V., J. Franco, Á. Borja and A. Fontán. - 2004 Hydrography of the southeastern Bay of Biscay. In: A. Borja and M. Collins (eds.), Oceanography and Marine Environment of the Basque Country, Elsevier Oceanography Series, 70: 160194, Amsterdam.

Walters, R. A. - 1986. A Finite Element Model for tidal and residual circulation. Comm. Appl. Numer. Meth., 2: 393-398.

Zienkiewicz, O.C. and J.C. Heinrich. - 1979. A unified treatment of steady state shallow water and two-dimensional Navier-Stokes equations-finite element penalty function approach. Comp. Meth. Appl. Mech. Engng., 17-18: 673-698.

Received July 4, 2002. Accepted November 24, 2004. 
